\title{
Impact of lake-river connectivity and interflow on the Canadian RCM simulated regional climate and hydrology for Northeast Canada
}

\author{
O. Huziy ${ }^{1}$ L. Sushama ${ }^{1}$
}

Received: 16 September 2015 / Accepted: 27 March 2016 / Published online: 5 April 2016

(c) The Author(s) 2016. This article is published with open access at Springerlink.com

\begin{abstract}
Lakes affect regional climate by modulating surface albedo, surface energy, and moisture budgets. This is especially important for regions such as Northeast Canada with approximately $10 \%$ of the landmass covered by lakes, wetlands and rivers. From the regional hydrology perspective, interactions between lakes and rivers are important as streamflow patterns can be significantly modified by lake storage, and similarly lake levels can be modified by streamflows. In this study, using a suite of experiments performed with the fifth generation Canadian Regional Climate Model (CRCM5) driven by the European Centre for Medium range Weather Forecasting ERA40 reanalysis data at the lateral boundaries for the 1979-2010 period, lake-river-atmosphere interactions and their impact on the regional climate/hydrology of north-east Canada are assessed. In these CRCM5 simulations, a one-dimensional lake model represents lakes, while the rivers are modeled using a distributed routing scheme, and one of the simulations includes interflow, i.e. lateral flow of water in the soil layers. Comparison of CRCM5 simulations with and without lakes suggests significant differences in winter/summer precipitation and winter temperature for the study region. CRCM5 simulations performed with and without lake-river interactions suggest improved representation of streamflows when lake storage and routing are taken into account. Adding the interflow process leads to increased streamflows during summer and fall seasons for the majority of the rivers, causing modest changes to land-atmosphere
\end{abstract}

O. Huziy

guziy.sasha@gmail.com

1 Centre ESCER (Étude Simulation du Climat à l'Échelle Régionale), University of Quebec at Montreal, Montreal H3C 3P8, Canada interactions via modified soil moisture. The impact of interflow on streamflow, obtained in this study, is comparable to the impact of lake-atmosphere interactions on streamflows. This study clearly demonstrates the need for realistic representation of lake-river interactions in regional climate models for realistic simulation of regional hydrology, particularly streamflows.

Keywords Regional climate modelling $\cdot$ Streamflow modelling $\cdot$ River modelling $\cdot$ Lake modelling $\cdot$ Lake-river interactions $\cdot$ Lake-atmosphere inter-actions

\section{Introduction}

Climate change will have significant impacts on water resources around the world due to the close connection between climate and the hydrologic cycle. Scientists agree on some of the important broad-scale features of the expected hydrologic changes, the most likely of which will be an intensification of the global hydrologic cycle, with an increase in the average global precipitation and evaporation as a direct consequence of warmer temperatures. However, there will be important regional differences in precipitation, runoff and recharge changes that are important to understand. This has led to an increased interest in assessing projected changes to hydrologic characteristics, including river flow regimes, at the regional scale (Hurkmans et al. 2010; Monk et al. 2011; Poitras et al. 2011; Forzieri et al. 2014). The conventional approach to study projected changes to streamflow is based on hydrologic models driven by outputs (precipitation and temperature) from transient climate change simulations performed with global climate models and regional climate models (GCMs and RCMs). Studies based on streamflow simulated by both GCMs (Falloon 
et al. 2011; Weiland et al. 2012) and RCMs (Poitras et al. 2011; Huziy et al. 2013) are on the rise though. RCMs and GCMs, with their complete closed water and energy budget including the atmospheric and land surface branches, are optimal tools to understand better the linkages and feedbacks between climate and hydrologic systems and to evaluate the impact of climate change on streamflows. Currently, RCMs offer higher spatial resolution than GCMs, allowing for greater topographic complexity and finer-scale atmospheric dynamics to be simulated and thereby representing a more adequate tool for generating the information required for regional impact studies. In a number of recent studies, RCMs have been used to study projected changes to various components of the hydrologic cycle (Jha et al. 2004; Wood et al. 2004; Kay et al. 2006a, b; Sushama et al. 2006; Graham et al. 2007a, b; Mladjic et al. 2010; Monk et al. 2011; Poitras et al. 2011). Therefore, to improve confidence in similar future work, this study focuses on improving the realism of RCM-simulated climate and hydrology, particularly streamflow, by introducing lakeriver interactions and interflow (i.e. lateral flow of water in the upper soil layers along the topographic slopes) in the regional climate model.

The role of lakes in modulating regional climate, through bigger thermal inertia, smaller roughness and smaller albedo (when not frozen) in comparison with the surrounding land areas, is well known (Samuelsson et al. 2010; Martynov et al. 2012; Notaro et al. 2013). Lakes also influence significantly the regional hydrology. For instance, Bowling and Lettenmaier (2010) demonstrated, for the northern coast of Alaska, that up to $80 \%$ of the snowmelt water could go to lake storage and thus does not contribute to the spring peak flow. Therefore, modelling lakes in climate models is important for better representation of streamflows. Lakes, in climate models, are generally represented using one-dimensional column lake models of different complexity (Hostetler et al. 1993; Mironov et al. 2010).

Other processes that are important for realistic simulation of streamflows include interflow, surface-groundwater interactions, land use changes, urbanization, irrigation etc., which are not usually represented in many climate models, including the fifth generation Canadian Regional Climate Model (CRCM5). Though interflow might be an important component, it has been neglected so far in climate models that did include simulation of runoff. This was a reasonable assumption at coarse resolutions, given that interflow depends on many parameters, such as horizontal hydraulic conductivity of soil, drainage density, for which the representativeness of up-scaled values might be questionable. At high resolutions it could be beneficial to parameterize interflow in RCMs (Soulis et al. 2000). For example, during intense precipitation events, the lateral flow could significantly increase the peak streamflow values in places where water impeding soil layers are near the surface (Chanasyk and Verschuren 1983). Soulis et al. (2000) and Wen et al. (2007) studied the impact of interflow and baseflow on streamflows using offline land surface scheme simulations. Though they obtained improvements in streamflow after modifying the land surface scheme, the effect of interflow alone was not clearly demonstrated. Moreover, Wen et al. (2007), in their simulations did not notice any significant changes to soil moisture with interflow and groundwater modifications in the land surface scheme, which might be the reason for the weak response of streamflow to interflow in their study.

The main objectives of this article therefore are to improve CRCM5 by modelling additional processes, i.e. lake-river interactions and interflow, to study lake-atmosphere and lake-river interactions, and their influence on regional climate and hydrology, particularly streamflows, for selected northeast Canadian watersheds spread mainly across the province of Quebec and parts of Ontario, Newfoundland and Labrador provinces. This region is selected because of the importance of rivers in the economic activities (notably hydropower generation) and the presence of a large number of small lakes for which the use of a 1D column lake model is appropriate. Though previous studies have looked at the impact of lakes on regional climate, to the best of our knowledge, no studies have looked at the impact of lakes on the regional hydrology, particularly streamflow, in the context of a regional climate modelling system.

The article is organized as follows. Section 2 describes models used in the study, i.e. the regional climate model, lake model and river routing approach and observation datasets used for validation purposes. Methodology, more specifically the design and purpose of the conducted experiments, is presented in Sect. 3. Results are presented in Sect. 4, followed by summary and conclusions in Sect. 5 .

\section{Models, experimental configuration and data}

The regional climate model used in this study is the CRCM5, which is based on a limited-area version of the Global Environment Multiscale (GEM) model used for numerical weather prediction at Environment Canada (Cote et al. 1998). GEM employs semi-Lagrangian transport and (quasi) fully implicit stepping scheme. In its fully elastic non-hydrostatic formulation (Yeh et al. 2002), GEM uses a vertical coordinate based on hydrostatic pressure (Laprise 


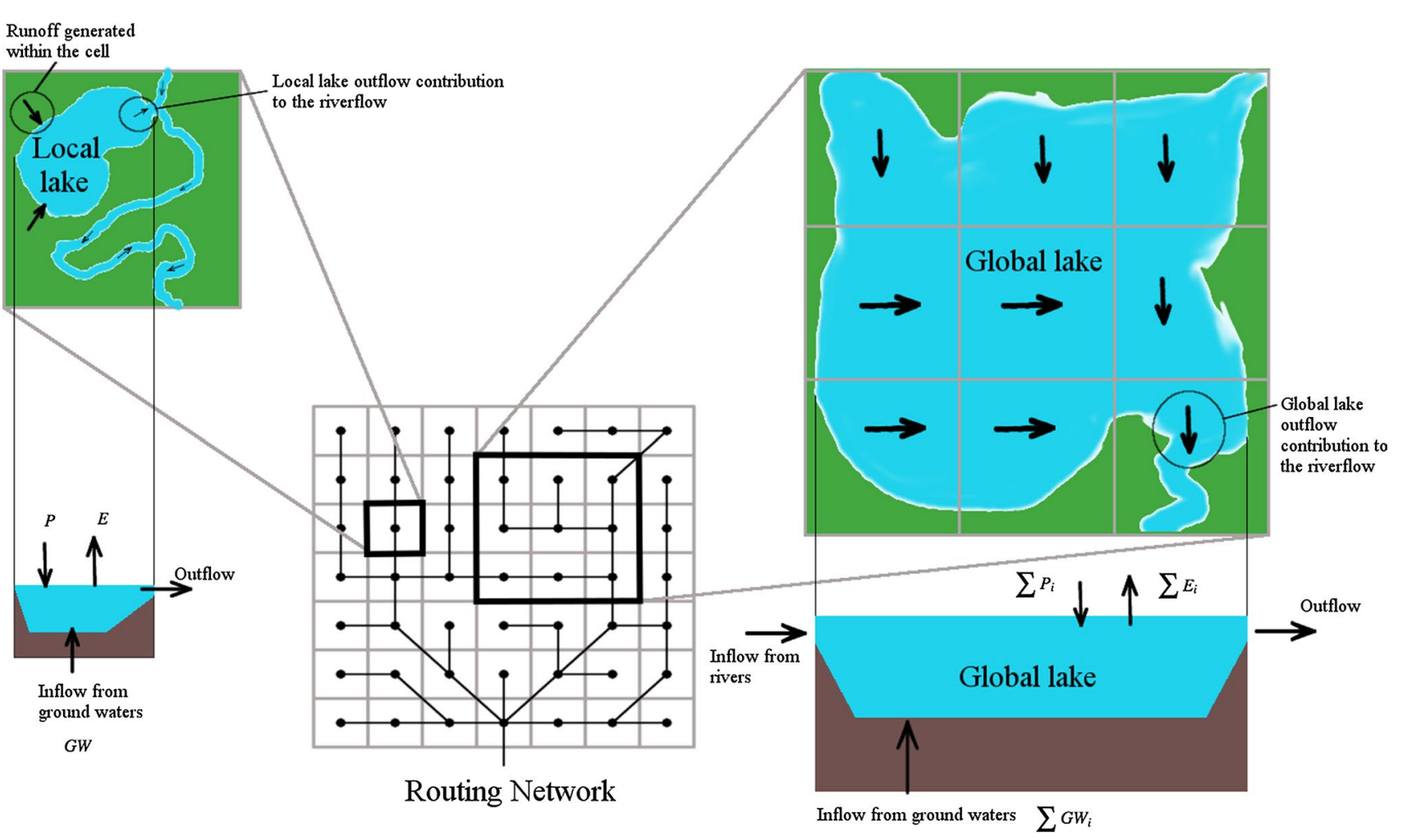

Fig. 1 Schematic of the representation of local and global lakes in the lake-river routing scheme

1992). The following physical parameterizations, inherited from GEM, are used in CRCM5: deep convection (Kain and Fritsch 1990), shallow convection (Kuo 1965), largescale condensation (Sundqvist et al. 1989), correlated-K solar and terrestrial radiations (Li and Barker 2005), subgrid-scale orographic gravity-wave drag (McFarlane 1987), low-level orographic blocking parameterization (Zadra et al. 2003, 2012) and planetary boundary layer parameterization (Benoit et al. 1989; Delage and Girard 1992; Delage 1997; Zadra et al. 2012).

The Canadian land-surface scheme CLASS version 3.5 (Verseghy 1991, 2009), which allows a flexible number of soil layers and depth, is used in CRCM5. Detailed description of the CRCM5 can be found in Martynov et al. (2012). Resolved and sub-grid lakes are represented in CRCM5 using the one-dimensional lake model developed by Hostetler (Martynov et al. 2012), where the vertical heat transfer is simulated by eddy conductivity and convective mixing (Hostetler et al. 1993). For the current study, a water balance of lakes is quantified by taking into account inflow/outflow from the upstream/downstream river, precipitation, lake evaporation as well as ice thaw and freeze. The influence of lake level variation on lake temperature profile is neglected in this study.

\subsection{River-lake routing model}

The river routing scheme WATROUTE (Soulis et al. 2000), modified to include ground water reservoir (Poitras et al. 2011), is used to simulate streamflows from runoff in CRCM5. The routing scheme solves the water balance equation at each grid cell and relates the water storage to streamflow using Manning's equation (Chow 1959).

Two types of lakes are distinguished for lake routing, local and global (Fig. 1). A grid cell is considered to have a local lake when the total lake fractional area of all lakes that fall within the cell is less than 0.6. A global lake, on the other hand, is spread over several grid cells and receives inflow from upstream cells. However, local lakes do not receive flow from upstream cells as it is assumed here that main streams usually do not flow through smaller local lakes. The only runoff contribution to the local lakes is from runoff generated within the same grid cell and the groundwater contribution of the same cell. However, the outflow from local lakes contributes to the river flow in the cell. The outflow from both local and global lakes is modelled using the storage-discharge function proposed by Döll et al. (2003): 
$Q(S)=k_{r} S\left(\frac{S}{S_{\max }}\right)^{1.5}$,

where $S$ is the active storage $\left[\mathrm{m}^{3}\right] ; S_{\max }$ is the maximum active storage $\left[\mathrm{m}^{3}\right]$, computed as $S_{\max }=H \cdot A_{\text {lake }}$, where $H$ is the maximum active storage depth [m], which is assumed to be equal $5 \mathrm{~m}, A_{\text {lake }}$ is the area of the lake; $k_{r}$ is the outflow coefficient $\left[\mathrm{d}^{-1}\right]$ (which is assumed to be equal 0.01 $\mathrm{d}^{-1}$ ). This relation, when applied for observed lake sites over the study domain, where lake levels and streamflows are available, gives satisfactory results. In addition, it also compares well with the equation proposed by Bowling and Lettenmaier (2010). In this study, the function from Döll et al. (2003) is used as it involves fewer parameters and provides reasonable results.

For local and global lakes, the change in lake level is calculated from the change in the lake storage as:

$\Delta h=\frac{\Delta S}{A_{\text {lake }}}$,

where $\Delta h$ is the change in the lake level, $\Delta S$ is the change in lake storage during the time step, and $A_{\text {lake }}$ is the lake area.

\subsection{Experimental configuration and observation data}

The integration domain of CRCM5 covers northeast Canada and is shown in Fig. 2a. Simulations are performed at $0.1^{\circ}$ horizontal resolution. The grid is uniform in the rotated latitude-longitude projection, with 56 hybrid vertical levels. For the land surface scheme CLASS, 26-layer soil configuration reaching $60 \mathrm{~m}$ is used. Such a deep CLASS configuration is chosen in order to better represent near-surface permafrost in the northern parts of the simulation domain (Paquin and Sushama 2015).

The land surface scheme recognizes four broad categories of vegetation, i.e. needle leaf, broadleaf, crops, and grass. These are specified in the model using USGS-GLCC dataset. The depth to bedrock, sand and clay fields needed for the soil model are specified from the 1 degree resolution datasets provided by Webb et al. (1993). These fields for the study domain are shown in Fig. 2c-e. Initial conditions for the soil temperature and soil liquid and frozen water contents are obtained by running CLASS offline for 300 years using atmospheric forcing for the 1961-1970 period from the European Centre for Medium range Weather Forecasting (ECMWF) ERA40 reanalysis data (Uppala et al. 2005), recursively; this data is available at 2.5 degree resolution. The depth of the modelled soil column justifies this long spinup period. (a)

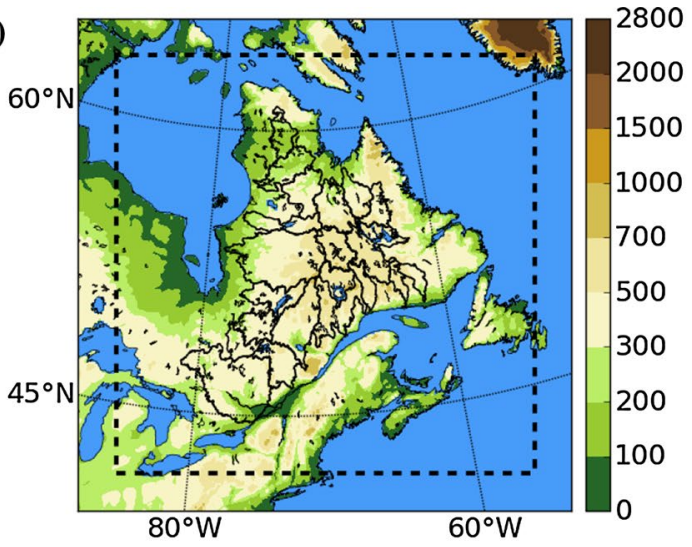

(b)

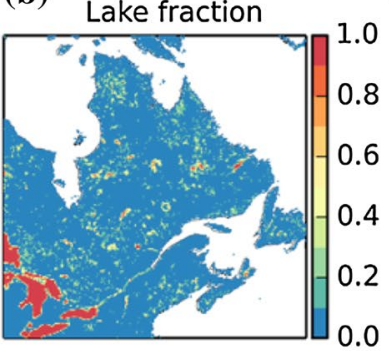

(d)

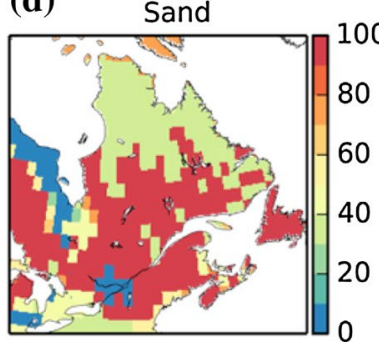

(c)

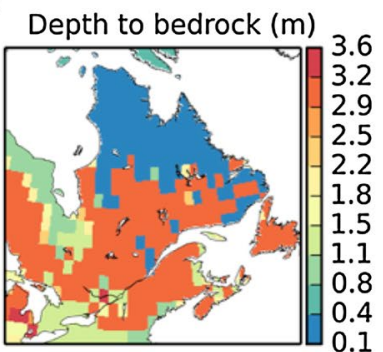

(e)

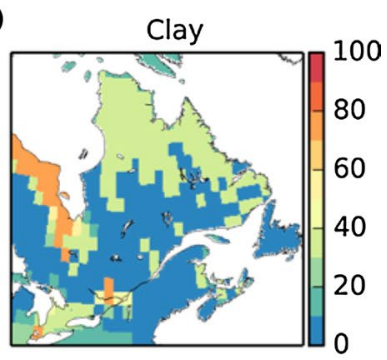

Fig. 2 a Simulation domain; the dashed line separates the blending and free zones. The colours correspond to topography $(\mathrm{m})$. Ocean and inland water bodies are shown in blue. Geophysical fields used in simulations: b lake fraction, $\mathbf{c}$ depth to bedrock, $\mathbf{d}$ percentage of sand and $\mathbf{e}$ percentage of clay

The lake fractions (Fig. 2b) over the domain are based on the Global Land Cover Characteristics (GLCC) dataset. According to this dataset, lakes cover $8 \%$ of the landmass within the integration domain. Nine percent of the grid cells with nonzero lake fraction have at least $60 \%$ of a grid cell area covered by lakes, i.e. the cells that are classified as global lake cells in this study. The flow directions, river lengths and slopes required by the routing scheme are derived from the HydroSHEDS database (Lehner et al. 2008), available at 30-s resolution on a latitude-longitude grid. Sea surface temperature and sea ice cover in the CRCM5 simulations are prescribed from ERA-Interim (ECMWF) reanalysis, available at 1.5 degree resolution (Dee et al. 2011). 
Table 1 List of simulations used in the current study

\begin{tabular}{llll}
\hline Simulation ID & Simulation period & Analysis period & Description \\
\hline CRCM5-NL & $1979-2010$ & $1991-2010$ & Lakes replaced with bare soil \\
CRCM5-L1 & $1979-2010$ & $1991-2010$ & Lakes simulated by Hostetler model, no lake routing \\
CRCM5-L2 & $1979-2010$ & $1991-2010$ & CRCM5-L1 + lake routing \\
CRCM5-L2I & $1979-2010$ & $1991-2010$ & CRCM5-L2 + interflow \\
\hline
\end{tabular}

For validation of simulated temperature and precipitation fields, daily analysis from Hopkinson et al. (2011) is used. This data is available at $10 \mathrm{~km}$ resolution over the study region south of $60^{\circ} \mathrm{N}$, for the 1970-2010 period. Snow water equivalent (SWE) simulated by the model is validated using daily gridded SWE dataset developed by Brown et al. (2003), which is available for the period 19801996 over North America at $0.25^{\circ}$ resolution. Simulated streamflow characteristics and lake levels are validated against observed streamflow and lake levels provided by the Centre d'expertise Hydrique du Québec (CEHQ; http:// www.cehq.gouv.qc.ca/). Six unregulated streamflow gauging stations, with lakes upstream, are selected for validation of the simulated streamflow. Three additional lake level gauging stations are also selected for validation purposes.

\section{Methodology}

As mentioned earlier, the objectives of this study are to improve CRCM5 by including additional processes, i.e. lake-river connectivity and interflow, and to study lakeatmosphere and lake-river interactions and its impact on regional climate and hydrology. To this end, four CRCM5 simulations (Table 1), as discussed below, driven by ERAInterim, are performed for the 1979-2010 period. The analysis is performed for the 1991-2010 period, as the first thirteen years of the simulation are considered as spin-up.

Simulation CRCM5-NL without lakes is the reference simulation. Lakes are replaced with bare soil in this simulation. The second simulation, CRCM5-L1, considers lakes, but lake routing is not considered. Lakes are represented in this simulation using Hostetler model (Hostetler et al. 1993). The influence of lakes on routing is only through the modification of atmospheric conditions by lakes. Comparison of this simulation with CRCM5-NL will help to quantify the effect of lake-atmosphere interactions on the regional climate (e.g. temperature, precipitation, latent and sensible heat fluxes) and its indirect effect on streamflow. The third simulation CRCM5-L2 is similar to CRCM5$\mathrm{L} 1$, but includes lake routing. It is used to study the direct influence of lakes on streamflow, i.e. to quantify the lag and damping effect of lakes on peak flows. Since this simulation accounts for both direct and indirect influence of lakes on rivers and the simulation CRCM5-L1 contains only the indirect link through modified atmospheric conditions, the effect of direct lake-river interactions can be evaluated by comparing CRCM5-L2 with CRCM5-L1.

The fourth experiment CRCM5-L2I is similar to CRCM5-L2, but considers interflow. Interflow is mostly driven by gravity, and the interflow formulation, used in this study, follows Soulis et al. (2000) and Mekonnen et al. (2012). According to this formulation, water movement is assumed to occur only along topographic slopes, and the influence of moisture gradients is neglected. The interflow rate $I(\mathrm{~m} / \mathrm{s})$ can then be derived, using the continuity and Darcian equations, as an explicit function of time $(t)$ elapsed since complete saturation of a soil layer:

$I=\frac{S R(t)-S R(t+\Delta t)}{\Delta t} H \theta_{S}$,

where $\Delta t$ is the model time step [s], and $H$ is the depth of the soil layer [m]. $S R(t)$ in the above equation is the liquid saturation ratio, i.e. the ratio of the current soil liquid water content $\theta$ to the maximum possible liquid soil water content $\theta_{S}$. It is a prognostic variable, calculated by the interflow model using the following expression:

$S R(t)= \begin{cases}1-\frac{t}{c t_{c}}, & t \leq t_{c} \\ \frac{c-1}{c}\left(\frac{t}{t_{c}}\right)^{1 /(c-1)}, & t>t_{c}\end{cases}$

where $t$ is the time elapsed [s] since total saturation of the soil layer; $t_{c}$ is the critical time [s], i.e. the time it takes for

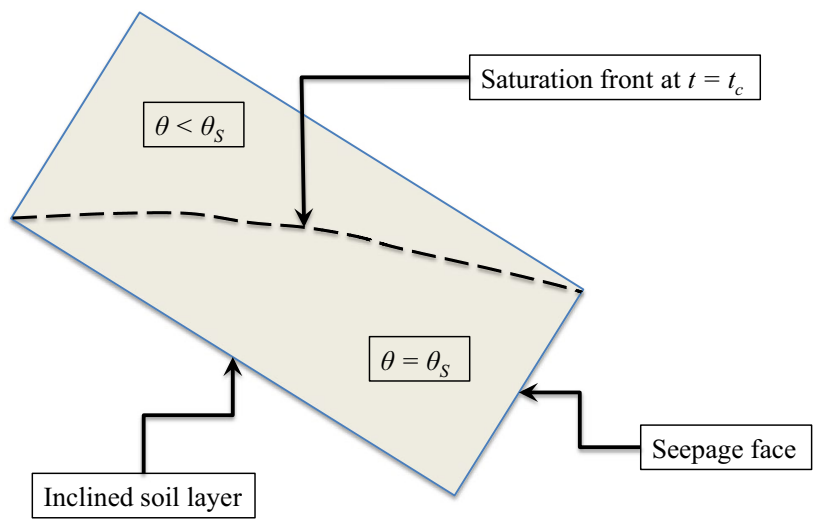

Fig. 3 Inclined soil layer and saturation front at the critical time $\left(t=t_{c}\right)$ when the interflow regime changes from linear to exponential function of time 

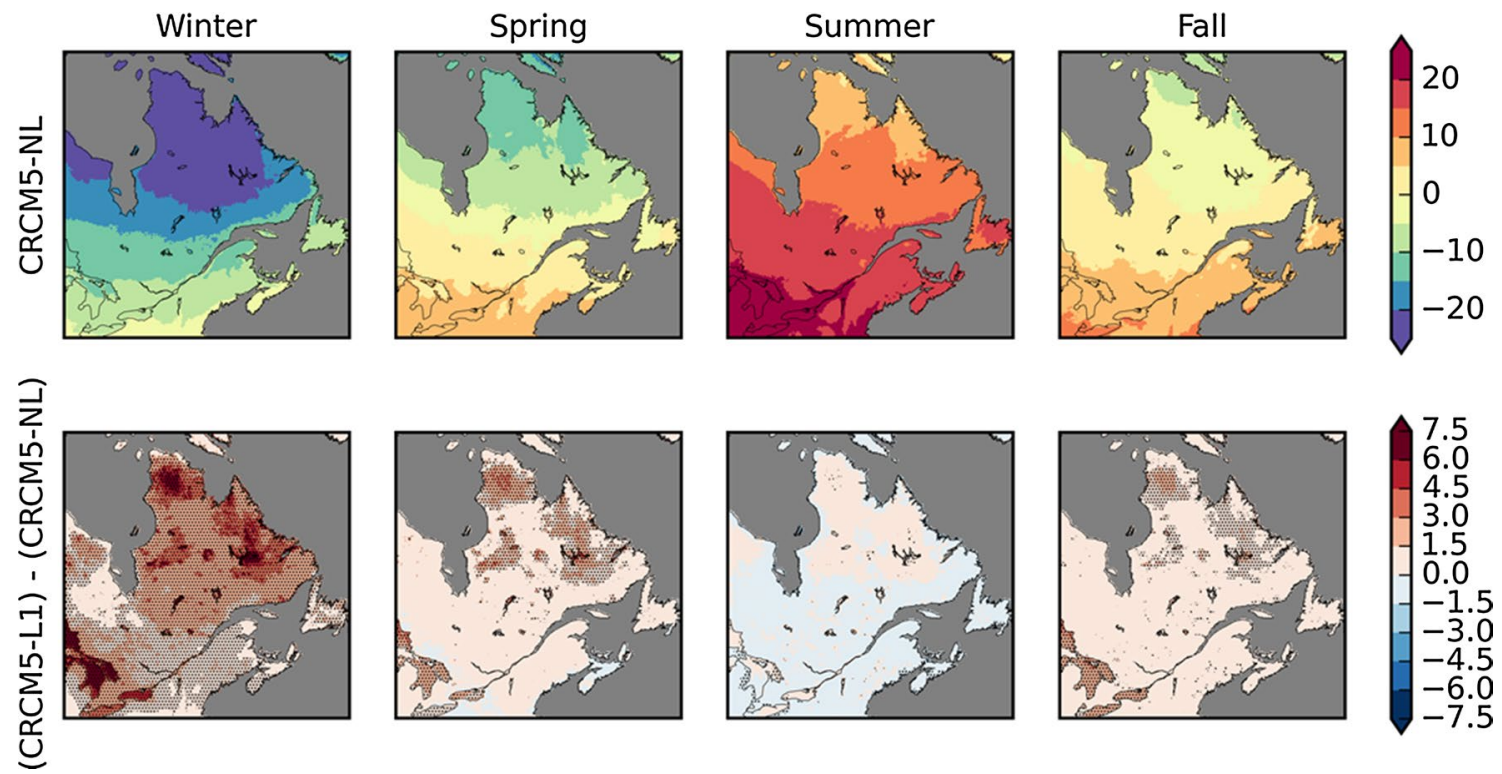

Fig. 4 Upper row CRCM5-NL simulated seasonal mean 2-m air temperatures (degrees Celsius), for the 1991-2010 period. Lower row difference between CRCM5-L1 and CRCM5-NL simulated mean

the saturation front to reach the seepage face of the soil layer (Fig. 3). In Eq. (4), $c=2 b+3$, where $b$ is a soil texture parameter presented in Clapp and Hornberger (1978).

Critical time is a function of drainage density, slope, horizontal hydraulic conductivity of soil and $\theta_{S}$ (Mekonnen et al. 2012). Drainage density, i.e. river network length per square kilometre of a watershed, is calculated from the HydroSHEDS. The river network for North America was available only to the south of $60^{\circ} \mathrm{N}$ in HydroSHEDS when this work was carried out. Therefore, grid cells not covered by the HydroSHEDS dataset are assigned mean values of the drainage density for the study domain. The horizontal hydraulic conductivity is assumed to decrease exponentially with depth. In order to derive the maximum value of the horizontal hydraulic conductivity, i.e. the value for the first soil layer, the vertical hydraulic conductivity of soil and anisotropy ratio of the layer are used. The anisotropy ratio is calculated based on sand and clay contents using the linear interpolation of the tabulated values of the anisotropy ratio from Fan et al. (2007).

\section{Results}

\subsection{Impact of lakes on regional climate and hydrology}

As was stated in the methodology section, effect of lakeatmosphere interactions on regional climate and streamflow seasonal 2-m air temperature. Black dots are used to show grid points where the differences are statistically significant at $10 \%$ significance level

is studied by comparing simulations with and without lakes, i.e. CRCM5-L1 and CRCM5-NL, respectively.

As expected, warmer temperatures are obtained with CRCM5-L1 compared to CRCM5-NL, particularly for winter, while a slight cooling is obtained in the southern part of the study domain during summer (Fig. 4). The warming effect of lake in winter is as high as $6{ }^{\circ} \mathrm{C}$, which is around 2 degrees warmer than the maximum winter warming reported by Martynov et al. (2012) for the same region, using CRCM5 at a coarser resolution. The cooling effect in spring is smaller and almost not visible after averaging over the March-May months. The summer cooling, associated with evaporative cooling, is more widespread, with cooling directly over lakes mostly visible during the June-July months (monthly figures are not shown). Though increased cloud cover can also contribute to this summer cooling, the very low non-significant differences in downwelling longwave radiation (Fig. 5) between the two simulations suggest no significant impact of cloud cover.

Impact of lakes on seasonal mean precipitation field is shown in Fig. 6. The simulation with lakes CRCM5-L1 has more precipitation compared to the simulation without lakes CRCMR-NL, for all seasons. Maximum differences of up to $60 \mathrm{~mm}$ in the total winter precipitation are noted. For summer, higher precipitation differences are generally located to the east of the Great Lakes. Samuelsson et al. (2010), in their study over Europe, showed that the effect of lakes could lead to both increases or decreases in total 

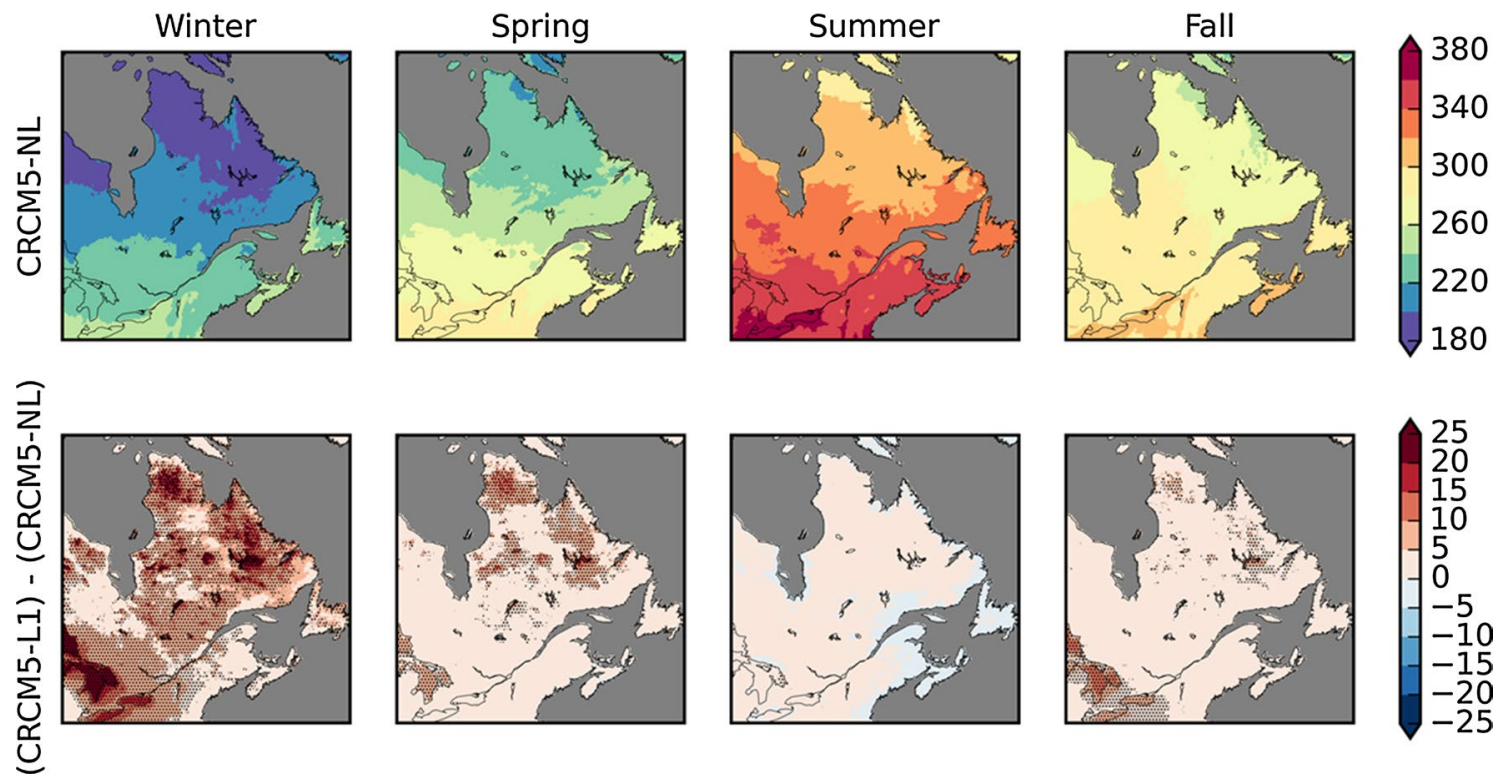

Fig. 5 Same as Fig. 4 but for down-welling long-wave radiation at the surface in W/m²
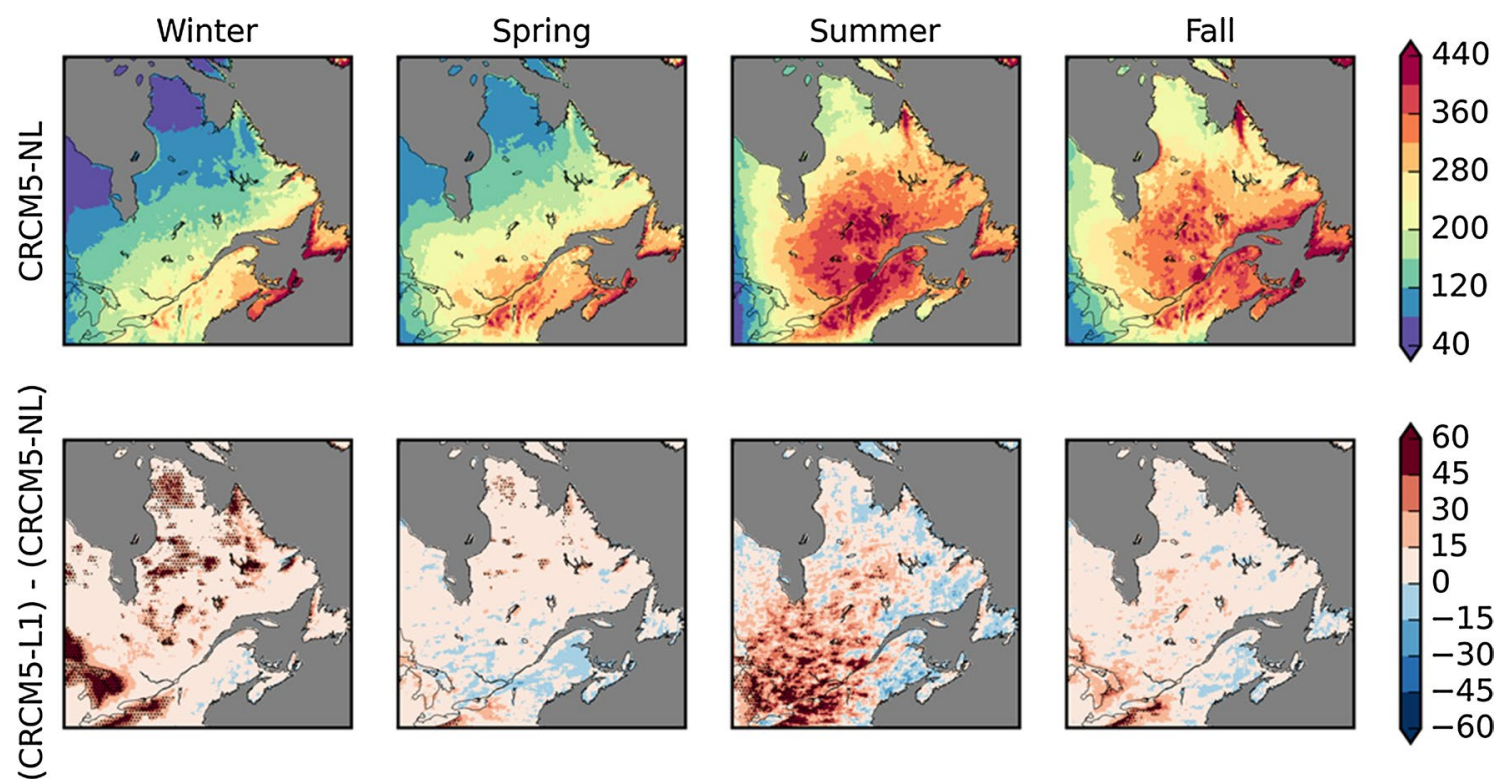

Fig. 6 Same as Fig. 4 but for total precipitation ( $\mathrm{mm} / \mathrm{season})$

precipitation (PR) during summer season. They reported an increase in precipitation in the case of shallow lakes and a decrease in the case of deep lakes. The decrease in precipitation for deep lakes in their study is probably due to the effect of cooler temperatures at depth compensating the destabilization caused by additional moisture in the air (Lofgren 1997).
Accounting lake contributions in the energy and humidity exchanges between the surface and atmosphere is expected to have an impact on streamflow mostly due to changes in precipitation. Figure 7 shows generally higher streamflows in CRCM5-L1 compared to CRCM5-NL, which is generally in agreement with the differences in precipitation between the two simulations (Fig. 6). There 

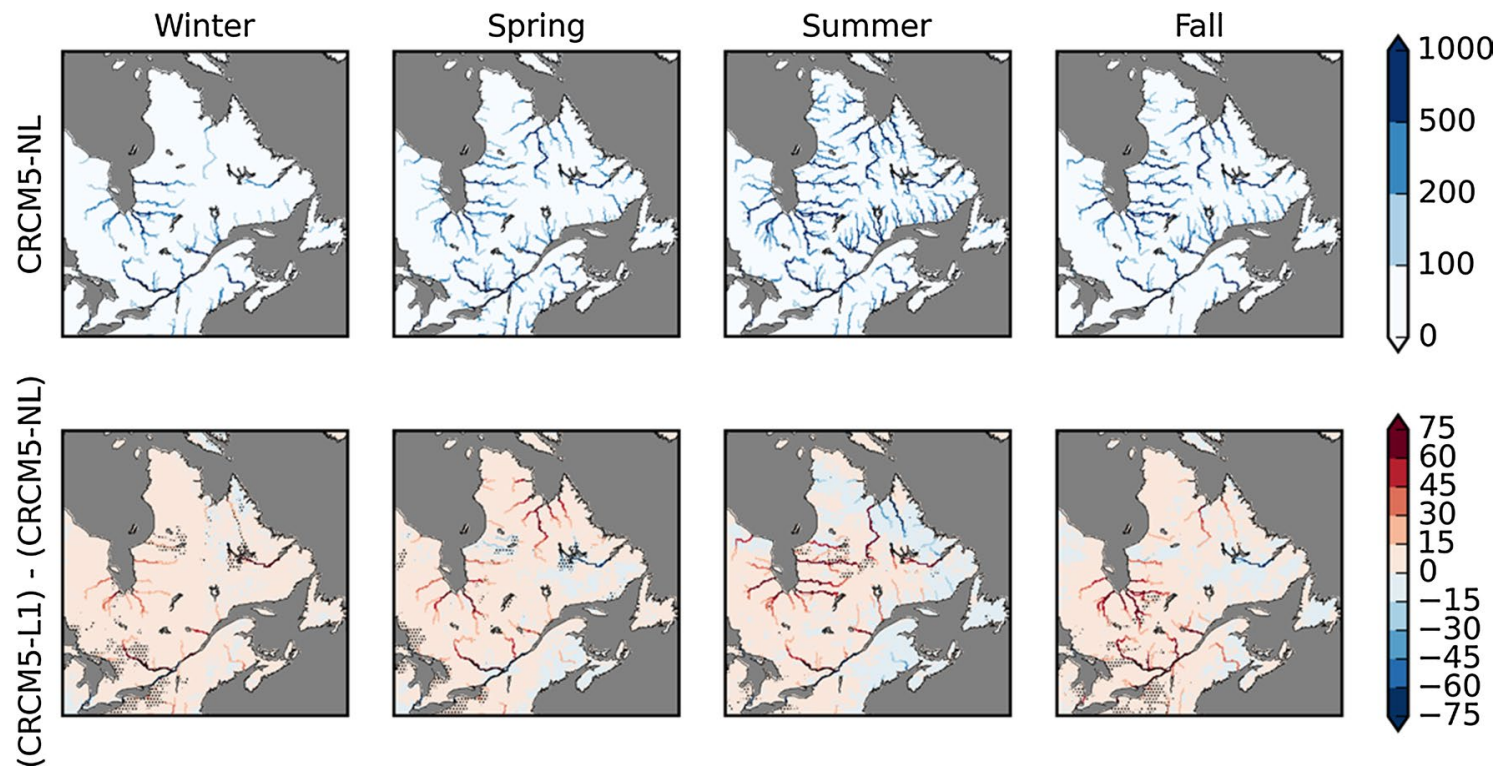

Fig. 7 Same as Fig. 4 but for streamflow $\left(\mathrm{m}^{3} / \mathrm{s}\right)$

are some regions, where streamflow values are lower in CRCM5-L1, particularly where there are sub-grid lakes, and this could be due to reduced runoff-contributing area due to the presence of lakes instead of bare soil.

In order to validate the simulated streamflows, six gauging stations are selected. The locations of these stations and their corresponding upstream areas, as seen by the model, are shown in Fig. 8a. The observed and modelled streamflows shown in Fig. 9 indicate an overestimation of spring peak flows by both CRCM5-NL and CRCM5-L1 for all stations. This overestimation is primarily due to the absence of lakes in CRCM5-NL, and absence of lake routing in CRCM5-L1. The overestimations for the northern stations (104001, 093801, 093806) are also related to the overestimation of winter SWE for the northern regions in both CRCM5-NL and CRCM5-L1 (Fig. 8b). The winter SWE is relatively better represented for the southern region in CRCM5L1 and CRCM5-NL. Generally, in CRCM-L1, where lake-atmosphere interactions are included, the volume of water flowing yearly through the selected gauging stations is higher than that for CRCM-NL and also the summer streamflows are slightly higher, due to higher precipitation in CRCM5-L1 compared to CRCM5-NL. However, the errors in the timing and magnitude of spring peak flows remain in both simulations, as lake routing and other processes are not considered in these two experiments. The impacts of lake routing and interflow are discussed below.

\subsection{Direct impact of lakes on streamflow}

Direct impact of lakes on streamflow is studied in this section by comparing simulations with (CRCM5-L2) and without (CRCM5-L1) lake routing.

Lakes retain snowmelt water and precipitation, acting as sinks/reservoirs in spring and summer. After summer they revert to supply water to rivers during autumn and winter seasons. Lakes are very important sources of water in winter. This is clearly visible in Fig. 10, which shows the spatial distribution of the effect of lake routing on seasonal mean streamflows. Fall and winter streamflows are clearly higher in CRCM5-L2, with winter differences statistically significant for most of the northern land regions. Spring flows are clearly reduced in CRCM5-L2 as lakes store part of the snowmelt.

Lake routing leads to better representation of spring peak flows in CRCM5-L2 (Fig. 11a), when upstream surface runoff dominates (093801), compared to the cases where subsurface runoff has greater influence on streamflow (081002). Nevertheless the improvement due to lake routing is robust and the comparison of modelled and observed hydrographs confirm this at other stations (Fig. 11a). The winter flow increases in CRCM5-L2 and is closer to observations in majority of the cases, especially for the northern stations. In these regions, the contribution of groundwater to streamflow during winter is almost negligible, due to the small soil moisture storage capacity of the thin soil layer, which is related to the proximity of bedrock 
Fig. 8 a Locations of streamflow gauging stations (red dots) and their corresponding upstream areas. b Differences between modelled (CRCM5-L1 in the upper row and CRCM5-

$\mathrm{NL}$ in the bottom row) and observed (Brown et al. 2003)

SWE (mm) for winter (DJF)

and for spring 2-m temperature (a)

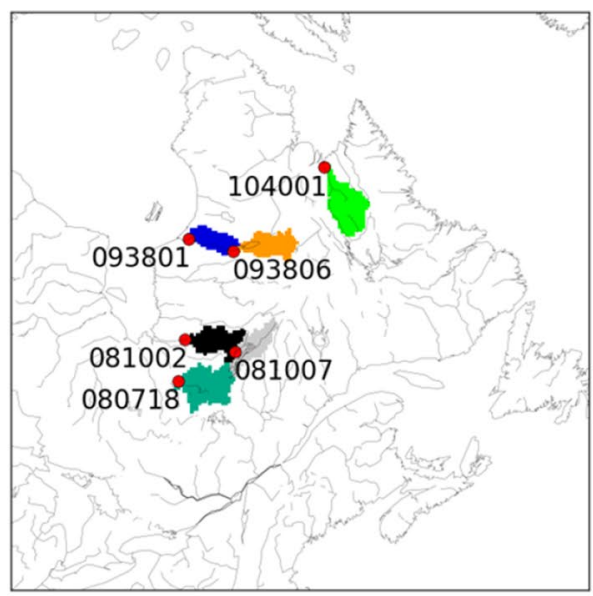

(b)
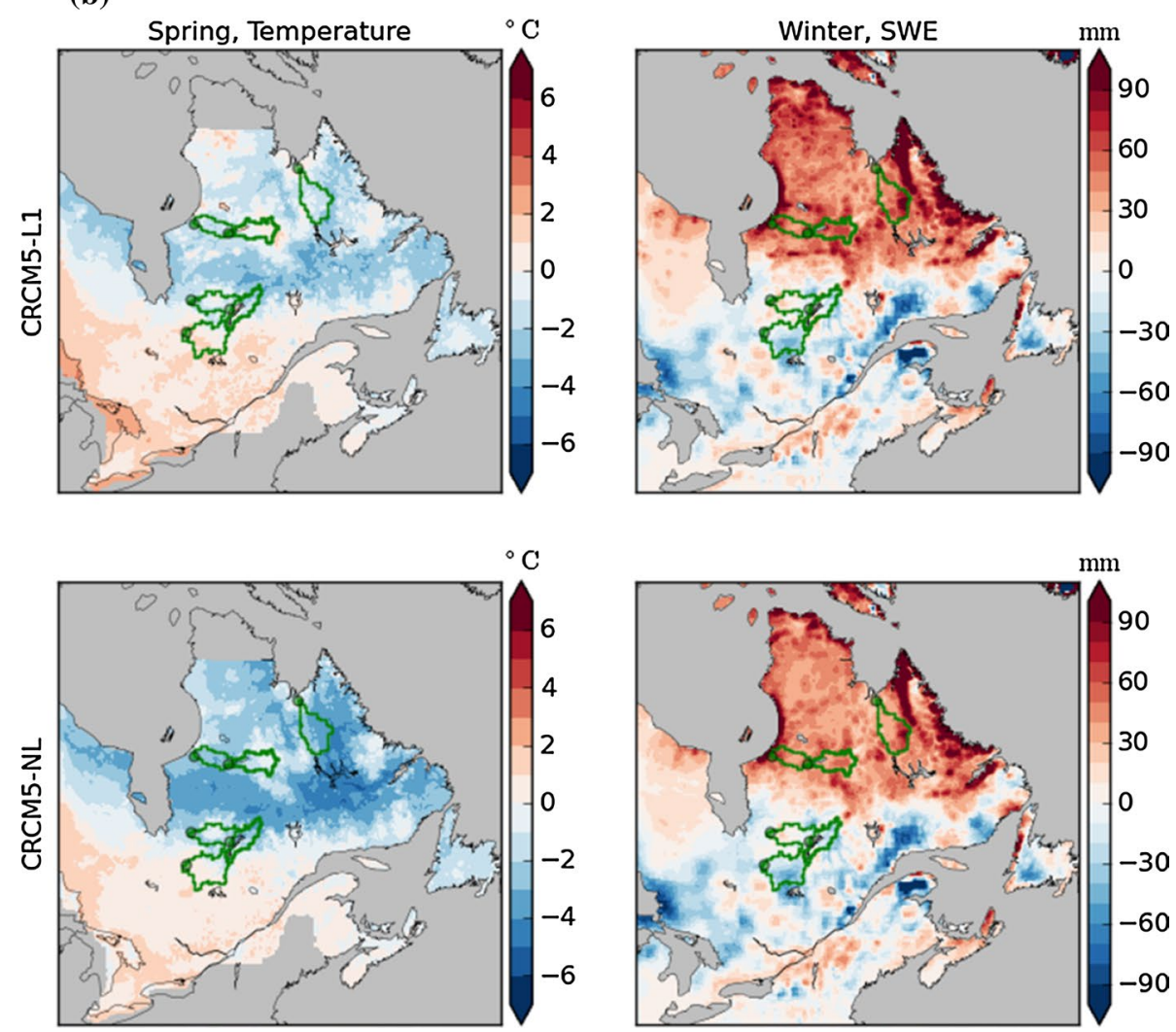

to the surface. During the fall season, streamflow is overestimated at all gauging stations. The overestimation can be partly explained by the overestimation of fall precipitation (figure not shown). The higher streamflow overestimation for the stations in regions with deeper bedrock (i.e., the southern stations) might be caused by uncertainties in soil parameters used to estimate infiltration, which then leads to the overestimation of drainage in spring, which is released into rivers later during fall season.

Figure $11 \mathrm{~b}$ shows scatter plots of the observed and modelled 10th and 90th percentiles (i.e. $Q_{10}$ and $Q_{90}$ ) of daily climatological streamflows. Lake routing improves model's ability in reproducing these characteristics. The 90th percentile, which is overestimated in CRCM5-L1 due to the 
Fig. 9 Comparison of the climatologic streamflow from experiments CRCM5-NL,

CRCM5-L1 and observations at selected gauging stations.

The panels are sorted according to the station latitude, i.e. the northernmost (southernmost) stations are shown in the top (bottom) panels
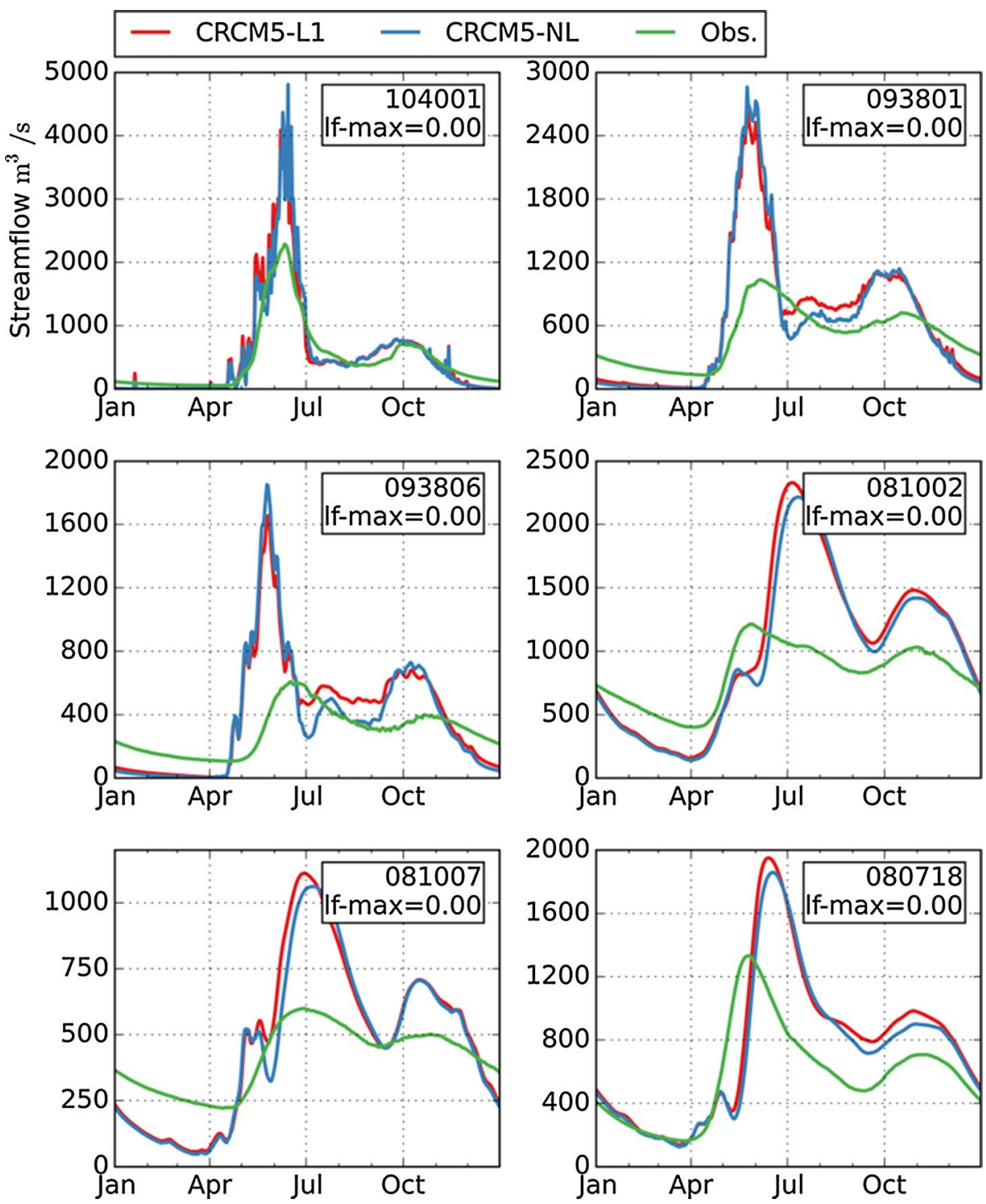

lack of lake storage during snowmelt, is improved for all stations when lake routing is considered. The 10th percentile, which is underestimated in CRCM5-L1 is improved through lake contribution to streamflows and are now closer to the observed values for the majority of the selected gauging stations, except for 080718. This is reflected in the $R^{2}$ values shown in Fig. 11b where it increases from 0.66 to 0.83 .

Implementation of lake-river interaction into the CRCM5 improves streamlow and allows to simulate lake level variations due to inflow into the lakes and outflow from lakes. The observed and CRCM5-L2 modelled mean annual cycle of lake level variation are shown in Fig. 12 for three lake level gauging stations (093807, 011502 and
040408). Relatively good agreement between modelled an observed lake level variations is evident from this figure. To further demonstrate the importance of lake-river connectivity in determining lake levels and its variability, lake level variability is determined for CRCM5-L2 at the same three gauging stations, considering only precipitation and evaporation, i.e., the streamflow contributions to lake water budget is neglected. This new lake level variability, named CRCM5-L2(P-E) is also plotted in Fig. 12. Clearly, streamflow cannot be neglected when calculating lake levels as this leads to a large discrepancy in simulated and observed lake level variations at all three gauging stations, suggesting the importance of the impact of lake-river connectivity on lake level variations. 

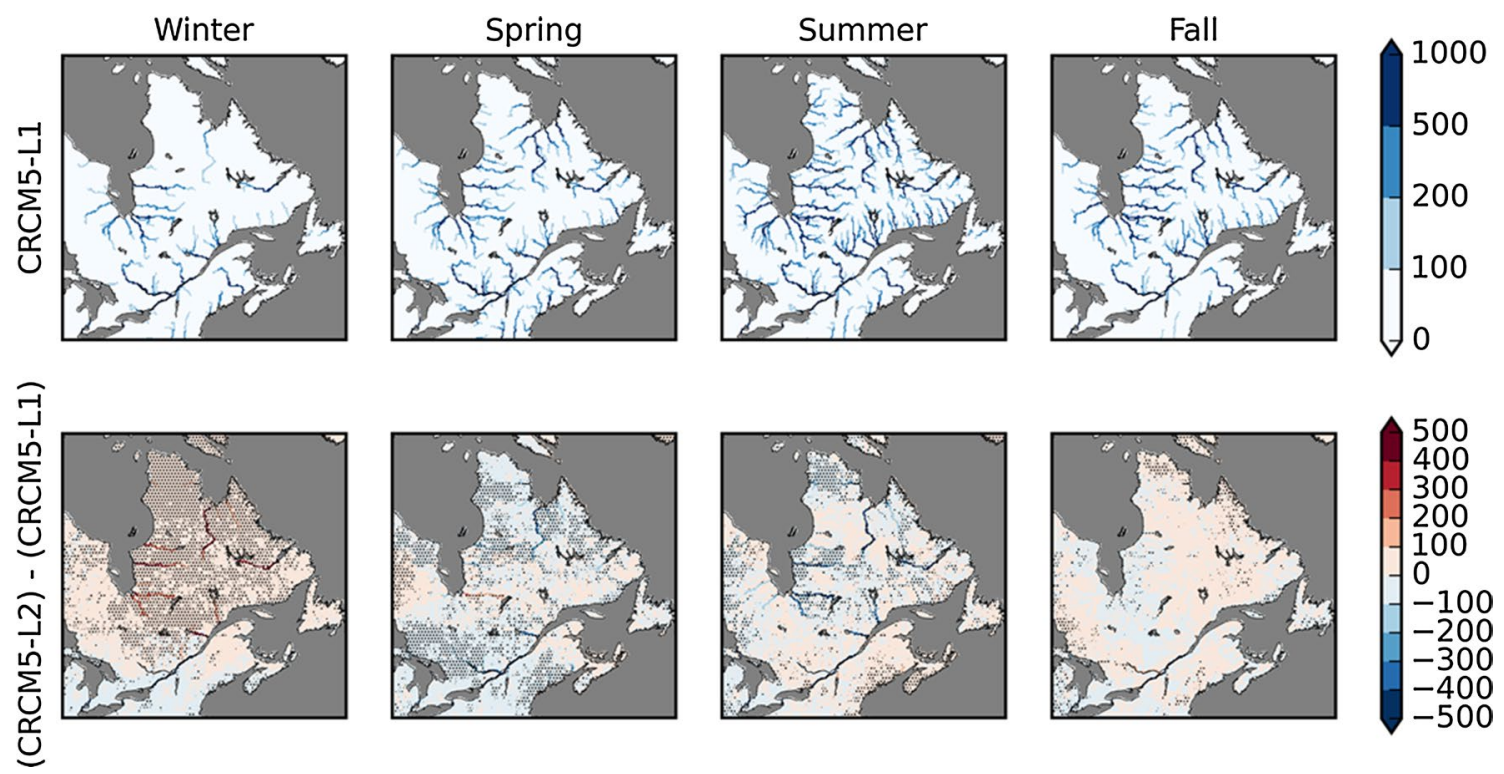

Fig. 10 Mean seasonal streamflow (upper row, for simulation CRCM5-L1) and changes to the mean streamflow due to lake routing (bottom row, i.e. CRCM5-L2 minus CRCM5-L1). All values are in

\subsection{Impact of interflow}

As discussed earlier, interflow process is considered in CRCM5-L2I simulation. The simulated zonally averaged mean interflow rate for the 1991-2010 period is shown in Fig. 13. The interflow process first starts in the southern part of the domain in March and then propagates northward following snowmelt. Interflow also occurs in summer and fall. It is associated with precipitation events in the southern parts of the region. However, this summer interflow is modest since the precipitation events that trigger interflow increases soil moisture only for a shorter period in comparison to snowmelt where the soil stays saturated for longer periods due to continuous infiltration of snowmelt water. Interflow in winter is practically zero due to frozen conditions, except in December over the southernmost parts of the region.

To study the impact of interflow on streamflows, the differences in streamflows for CRCM5-L2I and CRCM5-L2 are shown in the top row in Fig. 14, which suggests higher streamflows in CRCM5-L2I compared with CRCM5-L2, particularly visible for the major streams. However, some decreases can also be noted. To understand these differences, the surface and subsurface runoff/drainage and soil moisture fields are further analysed (Fig. 14). Note that the surface runoff in CRCM5-L2I includes interflow contribution. $\mathrm{m}^{3} / \mathrm{s}$. Dots show grid cells where the differences are statistically significant at $10 \%$ significance level

In general, higher surface runoff is noted over southerly and central regions during spring in CRCM5-L2I compared to CRCM5-L2. This is due to spring snowmelt, which saturates the soil, thereby enhancing lateral flows. Though lateral flows can lower soil moisture, the continuous infiltration of snowmelt water helps to maintain higher soil moisture levels and therefore lateral flows during spring. Once snowmelt ceases, i.e. during summer, the southernmost region shows reduced surface runoff in CRCM5-L2I due to reduced soil moisture caused by lateral flows and due to the absence of a continuous source of infiltration as during snowmelt. Regions of higher surface runoff in CRCM5-L2I compared to CRCM5-L2 migrates further north by summer, as snowmelt continues through the early part of summer for these regions. Statistically significant differences, with higher surface runoff values in CRCM5L2I, are noted for the southerly regions during summer, though it is not translated to significant changes in streamflows. This is due to higher interflow contribution to surface runoff associated with precipitation events. The relation between precipitation and interflow in this southern region in summer is confirmed by the positive correlation between precipitation and interflow (Fig. 15).

The impact of interflow on surface fluxes is now explored to see possible impacts on climate. The impact of interflow on the latent and sensible heat fluxes is very modest. The lower (higher) values of latent (sensible) heat 
Fig. 11 a Same as Fig. 9 but for simulations CRCM5-L1 and CRCM5-L2, b Scatter plots of 90th (left) and 10th percentiles (right) of the daily mean climatologic streamflows derived from observed and modelled (CRCM5-L1 and CRCM5-L2) streamflows
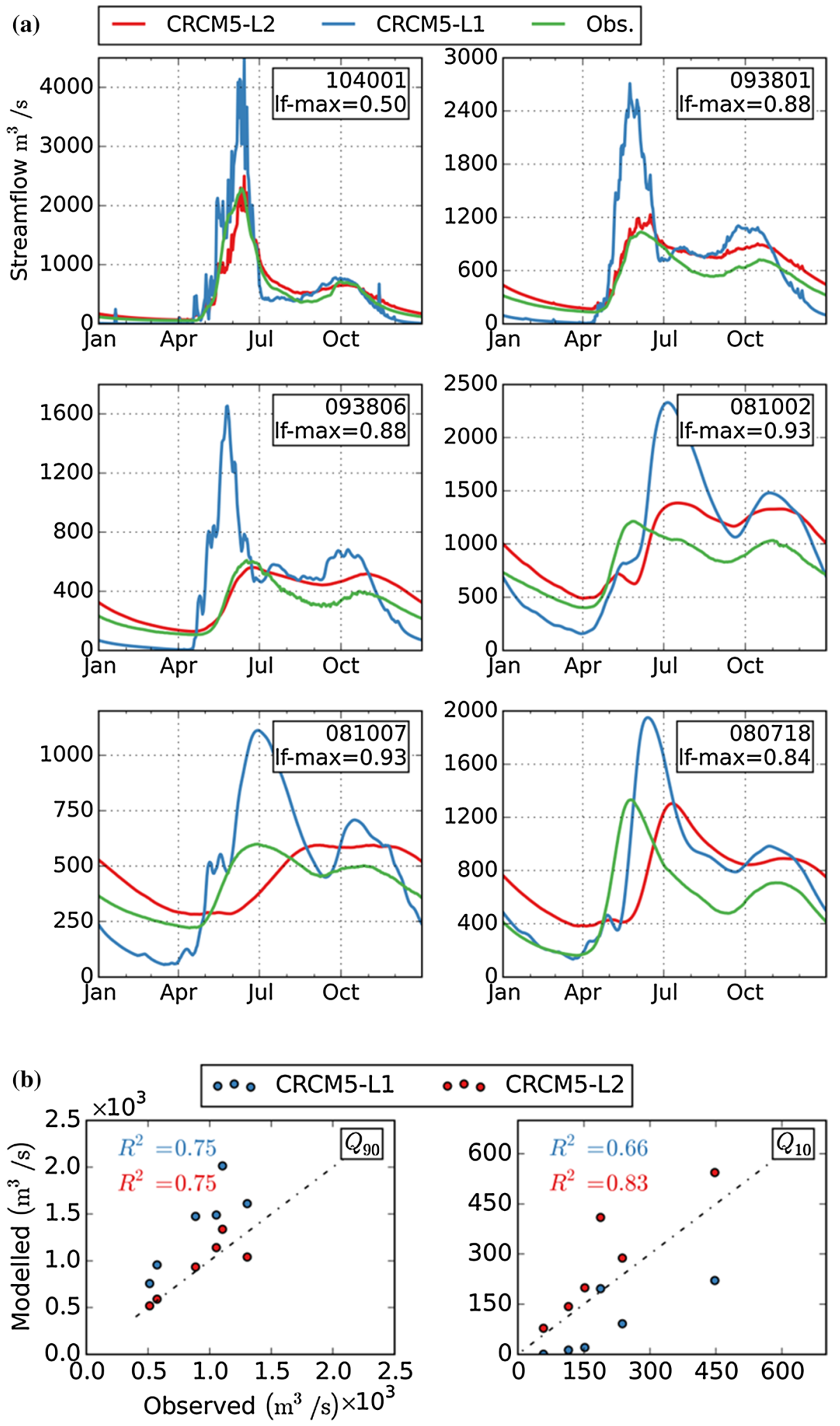

○。 CRCM5-L2

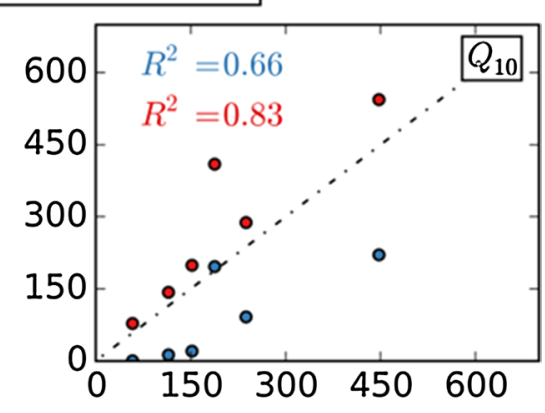


Fig. 12 a Locations and identification numbers of lake level gauging stations. b Mean annual cycle of observed and simulated daily lake level variations. CRCM5-L2 (red), CRCM5-L2(P-E) (blue), and observed (black, taken from CEHQ dataset)

Fig. 13 Zonally averaged mean interflow rate for the first soil layer, for the 1991-2010 period, for CRCM5-L2I
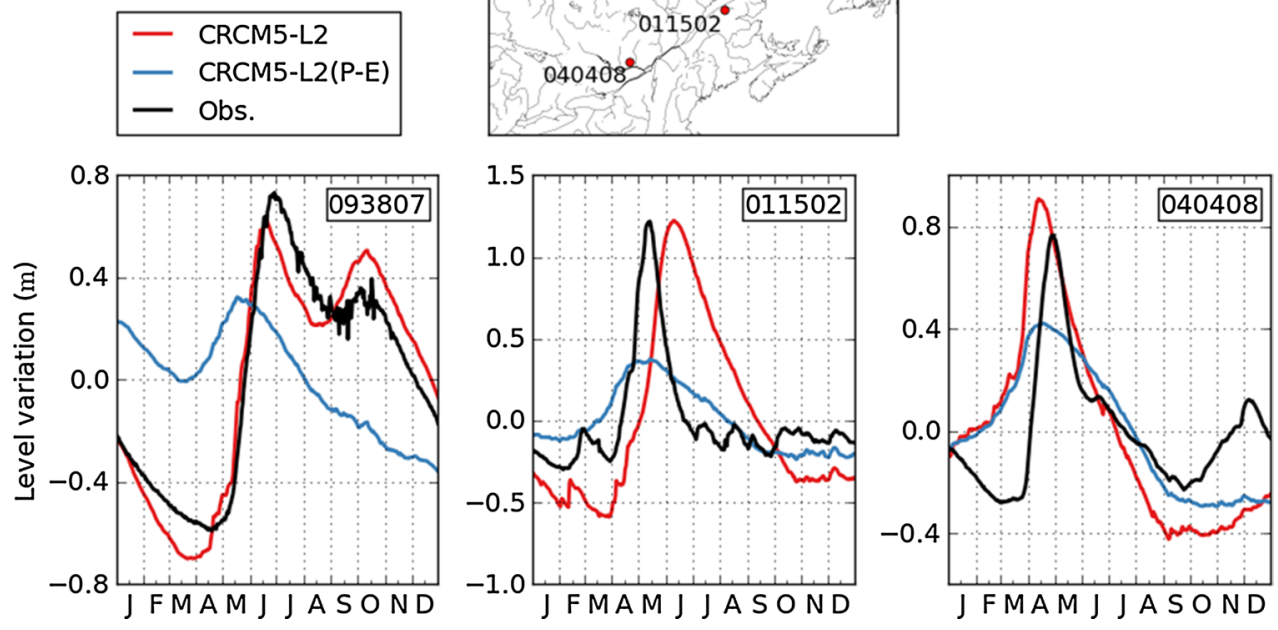

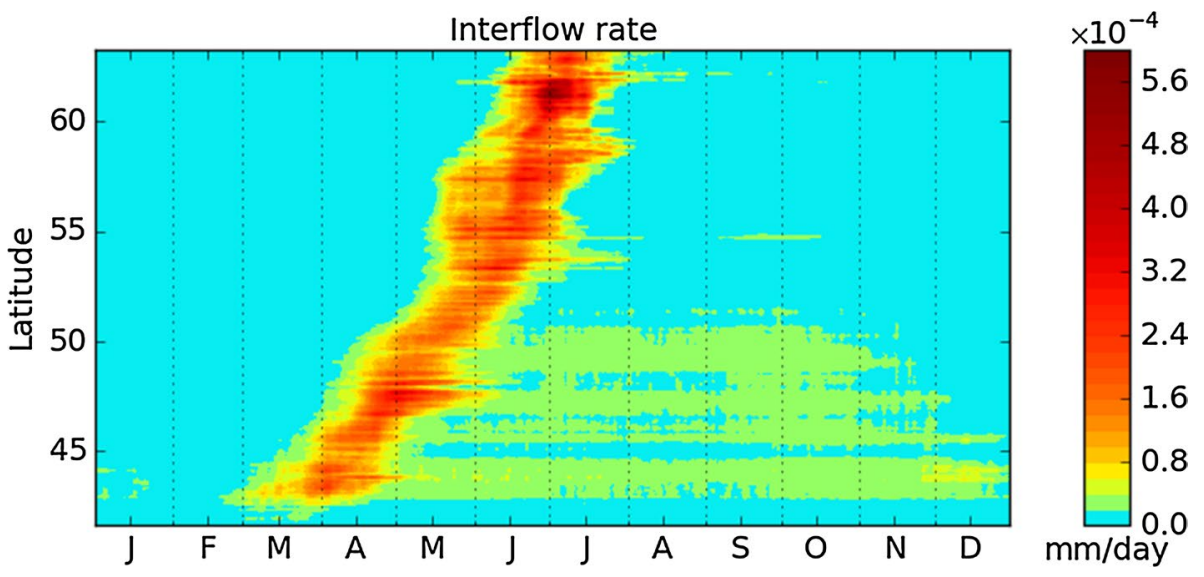

flux (figure not shown for sensible heat flux) in CRCM5L2I for the southern part of the domain in summer could partly be due to the reduced soil moisture in this simulation due to lateral flows. To understand better the connection between various variables, correlations of different interflow-related surface variables for CRCM5-L2I are studied (Fig. 15). In the northern and central parts of the study domain both interflow and latent heat flux increase at the same time in spring, which is signified by the high positive correlations in Fig. 15. This is because snowmelt increases both evaporation and infiltration and therefore interflow in spring, as is evident from the negative correlations between SWE and interflow and also between
SWE and latent heat flux. On the contrary, over a smaller southernmost part of the region, a negative correlation between latent heat flux and interflow rate is obtained in spring. This could be due to the decrease in the interflow rate caused by the decrease of soil moisture, both liquid and solid, and an increase in the evaporation caused by warmer temperatures. This region with negative correlation grows and displaces northward in summer (Fig. 15). The positive correlation between the interflow rate and soil ice content, as well as SWE, over the southernmost region suggests that the evaporation is enhanced at the same time as the interflow is suppressed in this part of the simulation domain during summer. 

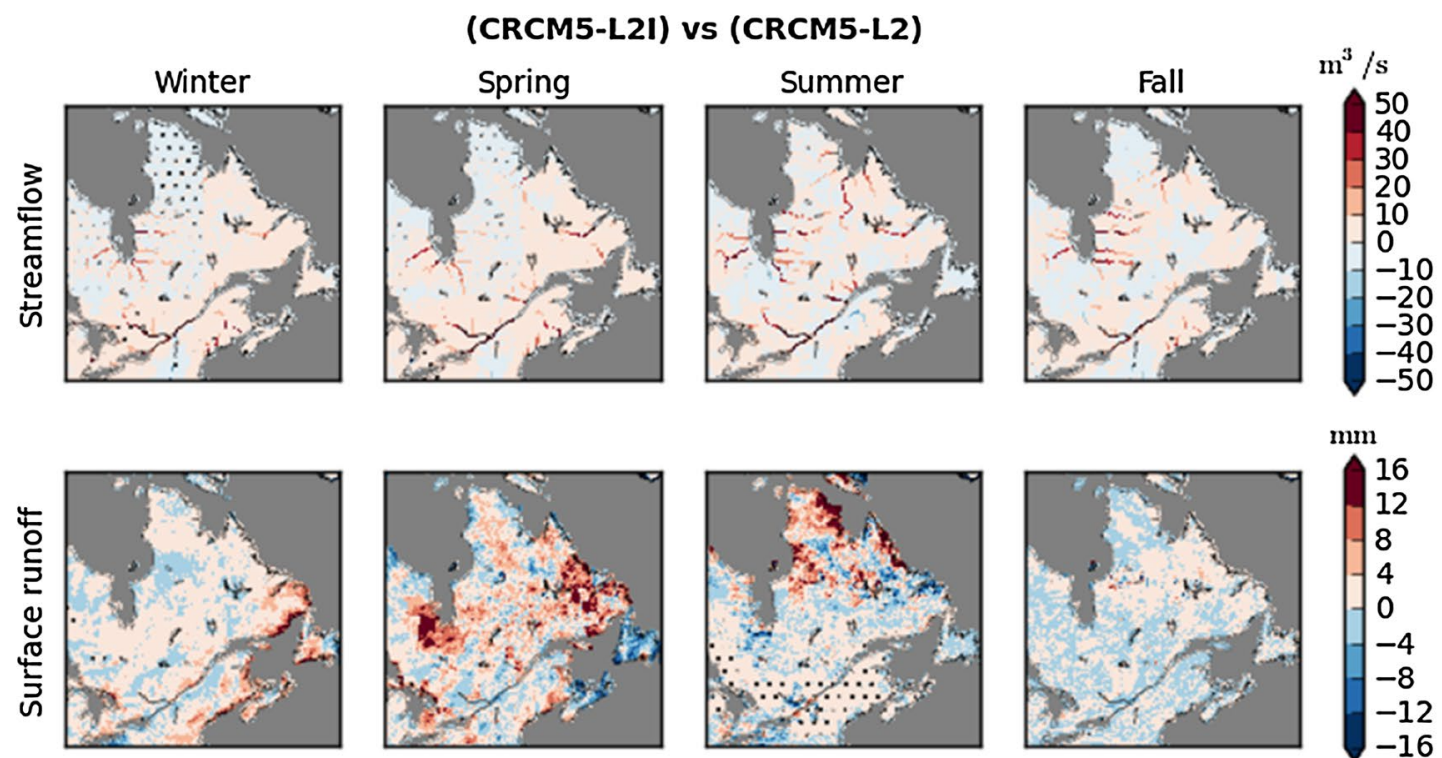

16
12
8
4
0
-4
-8
-12
-16
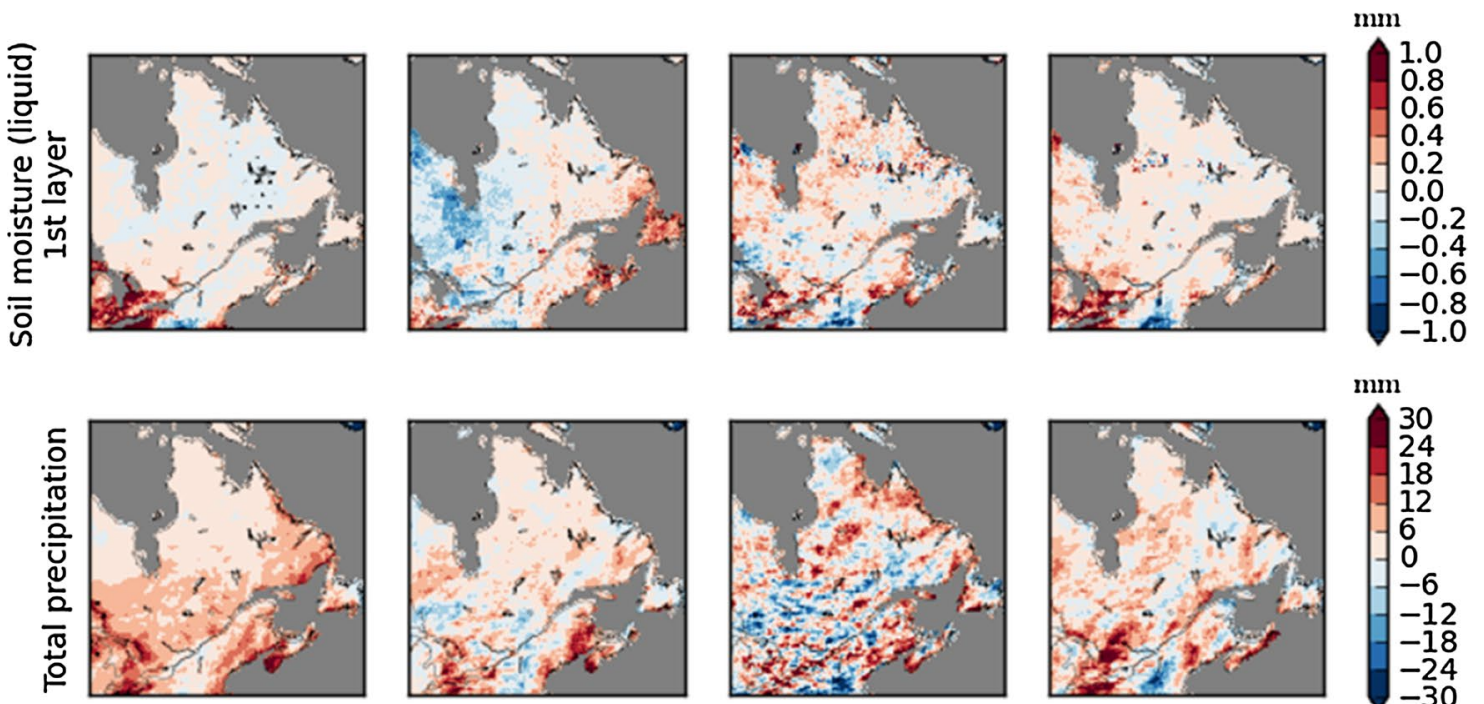

$\mathrm{mm}$
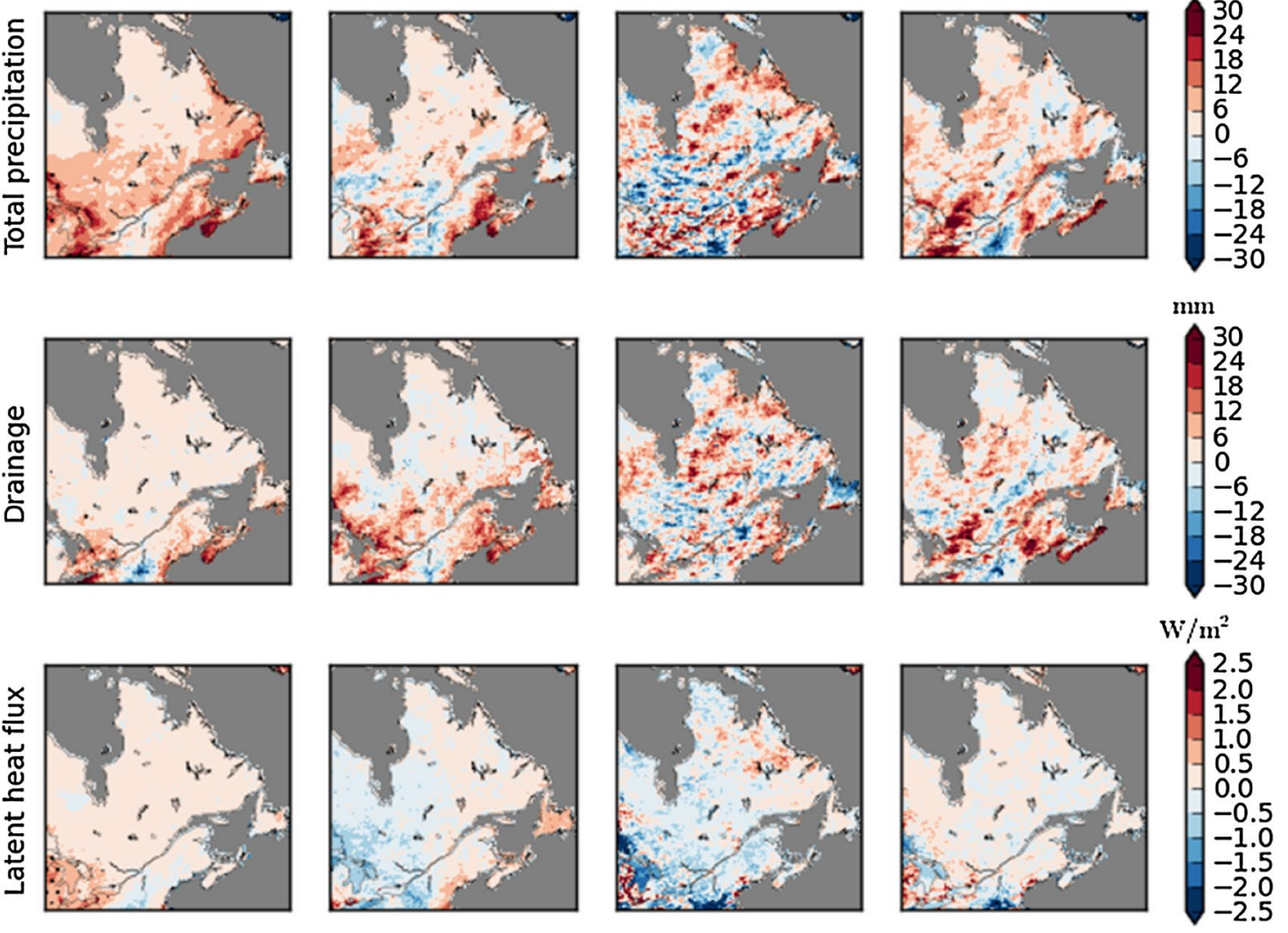

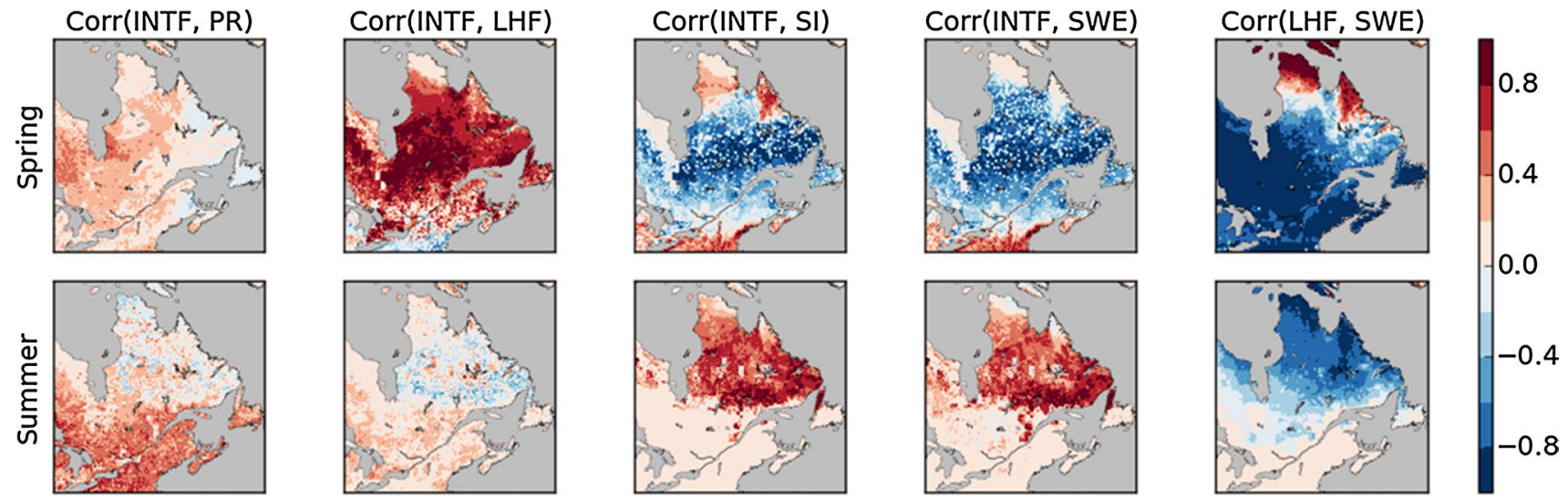

Fig. 15 Correlations between CRCM5-L2I variables, for the 1991-2010 period (INTF interflow rate in the top soil layer, $P R$ total precipitation rate, $S I$ soil ice fraction in the top soil layer, $S W E$ snow water equivalent, $L H F$ latent heat flux), for spring and summer seasons

4 Fig. 14 Differences between CRCM5-L2I and CRCM5-L2 simulated fields; from top to bottom are streamflow, surface runoff, moisture in the first soil layer, total precipitation, subsurface runoff and latent heat flux. Black dots indicate grid cells with statistically significant differences at $10 \%$ significance level

\section{Summary and conclusions}

Lakes and rivers cover approximately $10 \%$ of the Northeast Canadian landmass and therefore exert an important influence on the regional climate and hydrology. The main objective of this study was to understand lake-river connectivity and interflow processes and their impacts on regional climate and hydrology. Four CRCM5 simulations driven by ERA-Interim reanalysis at the lateral boundaries for the 1979-2010 period are presented in this paper. To begin with, impacts of lakes on the regional climate are assessed by comparing simulations with and without lakes. To study direct lake-river interactions, the simulations with and without lake routing are compared. Finally, the impact of lateral flows in the soil layers are assessed using the simulations with and without interflow.

Results based on the comparison of simulations with and without lakes show that lakes act to increase air temperature in winter and for the most part of summer, with the exception of larger lakes, where summertime evaporative cooling is more important. Lakes bring more moisture to the system and generally cause precipitation increases for all seasons.

Results from the simulations with and without lake routing suggest significant improvements to the timing and magnitude of spring peak flows and winter low flows. The indirect influence of lakes on rivers, obtained in this region, is modest in comparison with lake routing, i.e. the direct effect. The impact of rivers on lakes via lake inflows is found important to capture the variability of lake level. In summary, both simulated streamflows and lake levels benefit from lake routing.
Analysis of the simulation with interflow suggests maximum interflow during snowmelt periods. This is due to the high soil moisture level during this period due to snowmelt and therefore infiltration of snowmelt water. The effect of interflow on studied surface variables and fluxes is in general modest over the study domain. The effect of interflow on streamflows is mostly positive and is comparable to the effect of lake-atmosphere interactions on streamflows.

Although the study yields encouraging results with the 1D lake model applied to the lakes of all sizes, work is under way to use a 3D-model to represent the bigger lakes in CRCM5, which could improve mixing and capture the circulation patterns in lakes and consequently fluxes of humidity and heat between the lakes and the atmosphere. Adding the energy balance equation to the routing scheme and connecting lakes and rivers thermodynamically could also lead to a more comprehensive modelling tool, though the benefits at the current model resolutions might not be very significant.

There are many sources of uncertainties remaining in the runoff parameterization, such as errors in the geophysical fields. The version of CLASS used in the current study does not take into account vegetation characteristics when computing hydraulic conductivity of the soil, which might explain the small interflow values even in the forested areas. Therefore, future studies are required, to look into the sensitivity of the interflow parameterization to the soil parameters and to improve the representation of the impacts of vegetation on the soil hydraulic properties.

Simulated runoff and streamflow could also be further improved by considering interactions with ground water table and by improving the parameterization of hydraulic properties of frozen soil in CLASS. It must be noted that the results presented here are based on single simulation per configuration. To improve confidence in the results, it would be useful to perform an ensemble of simulations in 
future. It would also be useful to perform climate change simulations to assess the impact of lakes, lake-river connectivity and interflow process on projected changes to the regional climate and hydrology.

Acknowledgments This research was carried out within the Canadian Network for Regional Climate and Weather Processes (CNRCWP) project funded by the Natural Sciences and Engineering Research Council (NSERC) of Canada, with Ouranos as industrial partner.

Open Access This article is distributed under the terms of the Creative Commons Attribution 4.0 International License (http://creativecommons.org/licenses/by/4.0/), which permits unrestricted use, distribution, and reproduction in any medium, provided you give appropriate credit to the original author(s) and the source, provide a link to the Creative Commons license, and indicate if changes were made.

\section{References}

Benoit R, Cote J, Mailhot J (1989) Inclusion of a Tke boundary-layer parameterization in the Canadian regional finite-element model. Mon Weather Rev 117(8):1726-1750

Bowling LC, Lettenmaier DP (2010) Modeling the effects of Lakes and wetlands on the water balance of arctic environments. J Hydrometeorol 11(2):276-295

Brown RD, Brasnett B, Robinson D (2003) Gridded North American monthly snow depth and snow water equivalent for GCM evaluation. Atmos Ocean 41(1):1-14

Chanasyk DS, Verschuren JP (1983) An interflow model: I. Model development. Can Water Resourc J Revue Can Ressourc Hydr $8(1): 106-119$

Chow VT (1959) Open-channel hydraulics. McGraw-Hill, New York

Clapp RB, Hornberger GM (1978) Empirical equations for some soil hydraulic properties. Water Resour Res 14(4):601-604

Cote J, Gravel S, Methot A, Patoine A, Roch M, Staniforth A (1998) The operational CMC-MRB global environmental multiscale (GEM) model. Part I: design considerations and formulation. Mon Weather Rev 126(6):1373-1395

Dee DP, Uppala SM, Simmons AJ, Berrisford P, Poli P, Kobayashi S, Andrae U, Balmaseda MA, Balsamo G, Bauer P, Bechtold P, Beljaars ACM, van de Berg L, Bidlot J, Bormann N, Delsol C, Dragani R, Fuentes M, Geer AJ, Haimberger L, Healy SB, Hersbach H, Hólm EV, Isaksen L, Kållberg P, Köhler M, Matricardi M, McNally AP, Monge-Sanz BM, Morcrette JJ, Park BK, Peubey C, de Rosnay P, Tavolato C, Thépaut JN, Vitart F (2011) The ERA-Interim reanalysis: configuration and performance of the data assimilation system. Q J R Meteorol Soc 137(656):553-597

Delage Y (1997) Parameterising sub-grid scale vertical transport in atmospheric models under statically stable conditions. BoundLayer Meteorol 82(1):23-48

Delage Y, Girard C (1992) Stability functions correct at the free-convection limit and consistent for both the surface and Ekman layers. Bound-Layer Meteorol 58(1-2):19-31

Döll P, Kaspar F, Lehner B (2003) A global hydrological model for deriving water availability indicators: model tuning and validation. J Hydrol 270(1-2):105-134

Falloon P, Betts R, Wiltshire A, Dankers R, Mathison C, McNeall D, Bates P, Trigg M (2011) Validation of river flows in HadGEM1 and HadCM3 with the TRIP river flow model. J Hydrometeorol 12(6):1157-1180
Fan Y, Miguez-Macho G, Weaver CP, Walko R, Robock A (2007) Incorporating water table dynamics in climate modeling: 1. Water table observations and equilibrium water table simulations. J Geophys Res Atmos 112(D10):D10125

Forzieri G, Feyen L, Rojas R, Flörke M, Wimmer F, Bianchi A (2014) Ensemble projections of future streamflow droughts in Europe. Hydrol Earth Syst Sci 18(1):85-108

Graham LP, Andreasson J, Carlsson B (2007a) Assessing climate change impacts on hydrology from an ensemble of regional climate models, model scales and linking methods-a case study on the Lule River basin. Clim Change 81:293-307

Graham LP, Hagemann S, Jaun S, Beniston M (2007b) On interpreting hydrological change from regional climate models. Clim Change 81:97-122

Hopkinson RF, McKenney DW, Milewska EJ, Hutchinson MF, Papadopol P, Vincent LA (2011) Impact of aligning climatological day on gridding daily maximum-minimum temperature and precipitation over Canada. J Appl Meteorol Climatol 50(8):1654-1665

Hostetler SW, Bates GT, Giorgi F (1993) Interactive coupling of a lake thermal-model with a regional climate model. J Geophys Res Atmos 98(D3):5045-5057

Hurkmans R, Terink W, Uijlenhoet R, Torfs P, Jacob D, Troch PA (2010) Changes in streamflow dynamics in the rhine basin under three high-resolution regional climate scenarios. J Clim 23(3):679-699

Huziy O, Sushama L, Khaliq M, Laprise R, Lehner B, Roy R (2013) Analysis of streamflow characteristics over Northeastern Canada in a changing climate. Clim Dyn 40(7):1879-1901

Jha M, Pan ZT, Takle ES, Gu R (2004) Impacts of climate change on streamflow in the Upper Mississippi River Basin: a regional climate model perspective. J Geophys Res Atmos 109(D9):D09105

Kain JS, Fritsch JM (1990) A one-dimensional entraining detraining plume model and its application in convective parameterization. J Atmos Sci 47(23):2784-2802

Kay AL, Jones RG, Reynard NS (2006a) RCM rainfall for UK flood frequency estimation. II. Climate change results. J Hydrol 318(1-4):163-172

Kay AL, Reynard NS, Jones RG (2006b) RCM rainfall for UK flood frequency estimation. I. Method and validation. J Hydrol 318(1-4):151-162

Kuo H-L (1965) On formation and intensification of tropical cyclones through latent heat release by cumulus convection. J Atmos Sci 22(1):40-63

Laprise R (1992) The Euler equations of motion with hydrostatic pressure as an independent variable. Mon Weather Rev 120(1):197-207

Lehner B, Verdin K, Jarvis A (2008) New global hydrography derived from spaceborne elevation data. EOS Trans AGU 89(10):93

Li J, Barker HW (2005) A radiation algorithm with correlated$\mathrm{k}$ distribution. Part I: local thermal equilibrium. J Atmos Sci 62(2):286-309

Lofgren BM (1997) Simulated effects of idealized Laurentian Great Lakes on regional and large-scale climate. J Clim 10(11):2847-2858

Martynov A, Sushama L, Laprise R, Winger K, Dugas B (2012) Interactive lakes in the Canadian regional climate model, version 5: the role of lakes in the regional climate of North America, 2012, p 64

McFarlane NA (1987) The effect of orographically excited gravity wave drag on the general circulation of the lower stratosphere and troposphere. J Atmos Sci 44(14):1775-1800

Mekonnen M, Soulis R, Fortin V, Davison B, Marin S, Wilson R (2012) WATDRN: enhanced hydrology for CLASS. Technical paper 
Mironov D, Heise E, Kourzeneva E, Ritter B, Schneider N, Terzhevik A (2010) Implementation of the lake parameterisation scheme FLake into the numerical weather prediction model COSMO. Boreal Environ Res 15(2):218-230

Mladjic B, Sushama L, Khaliq MN, Laprise R, Caya D, Roy R (2010) Canadian RCM projected changes to extreme precipitation characteristics over Canada. J Clim 24(10):2565-2584

Monk WA, Peters DL, Allen Curry R, Baird DJ (2011) Quantifying trends in indicator hydroecological variables for regime-based groups of Canadian rivers. Hydrol Process 25(19):3086-3100

Notaro M, Holman K, Zarrin A, Fluck E, Vavrus S, Bennington V (2013) Influence of the Laurentian great lakes on regional climate. J Clim 26(3):789-804

Paquin JP, Sushama L (2015) On the Arctic near-surface permafrost and climate sensitivities to soil and snow model formulations in climate models. Clim Dyn 44(1-2):203-228

Poitras V, Sushama L, Seglenieks F, Khaliq MN, Soulis E (2011) Projected changes to streamflow characteristics over Western Canada as simulated by the Canadian RCM. J Hydrometeorol 12(6):1395-1413

Samuelsson P, Kourzeneva E, Mironov D (2010) The impact of lakes on the European climate as simulated by a regional climate model. Boreal Environ Res 15(2):113-129

Soulis ED, Snelgrove KR, Kouwen N, Seglenieks F, Verseghy DL (2000) Towards closing the vertical water balance in Canadian atmospheric models: coupling of the Land Surface Scheme CLASS with the distributed hydrological model WATFLOOD. Atmos Ocean 38(1):251-269

Sundqvist H, Berge E, Kristjánsson JE (1989) Condensation and cloud parameterization studies with a mesoscale numerical weather prediction model. Mon Weather Rev 117(8):1641-1657

Sushama L, Laprise R, Caya D, Frigon A, Slivitzky M (2006) Canadian RCM projected climate-change signal and its sensitivity to model errors. Int J Climatol 26(15):2141-2159

Uppala SM, Kallberg PW, Simmons AJ, Andrae U, Bechtold VD, Fiorino M, Gibson JK, Haseler J, Hernandez A, Kelly GA, Li X, Onogi K, Saarinen S, Sokka N, Allan RP, Andersson E, Arpe K, Balmaseda MA, Beljaars ACM, Van De Berg L, Bidlot J,
Bormann N, Caires S, Chevallier F, Dethof A, Dragosavac M, Fisher M, Fuentes M, Hagemann S, Holm E, Hoskins BJ, Isaksen L, Janssen PAEM, Jenne R, McNally AP, Mahfouf JF, Morcrette JJ, Rayner NA, Saunders RW, Simon P, Sterl A, Trenberth KE, Untch A, Vasiljevic D, Viterbo P, Woollen J (2005) The ERA-40 re-analysis. Q J R Meteorol Soc 131(612):2961-3012

Verseghy DL (1991) Class-a Canadian land surface scheme for GCMS. 1. Soil Model. Int J Climatol 11(2):111-133

Verseghy DL (2009) CLASS - the Canadian land surface scheme (version 3.4) technical documentation (version 1.1). Environment Canada, Climate Research Division, Science and Technology Branch, Downsview, ON

Webb RS, Rosenzweig CE, Levine ER (1993) Specifying land surface characteristics in general-circulation models-soil-profile data set and derived water-holding capacities. Global Biogeochem Cycles 7(1):97-108

Weiland FCS, van Beek LPH, Kwadijk JCJ, Bierkens MFP (2012) On the suitability of GCM runoff fields for river discharge modeling: a case study using model output from HadGEM2 and ECHAM5. J Hydrometeorol 13(1):140-154

Wen L, Wu Z, Lu G, Lin CA, Zhang J, Yang Y (2007) Analysis and improvement of runoff generation in the land surface scheme CLASS and comparison with field measurements from China. $\mathrm{J}$ Hydrol 345(1-2):1-15

Wood AW, Leung LR, Sridhar V, Lettenmaier DP (2004) Hydrologic implications of dynamical and statistical approaches to downscaling climate model outputs. Clim Change 62(1-3):189-216

Yeh KS, Cote J, Gravel S, Methot A, Patoine A, Roch M, Staniforth A (2002) The CMC-MRB global environmental multiscale (GEM) model. Part III: nonhydrostatic formulation. Mon Weather Rev 130(2):339-356

Zadra A, Roch M, Laroche S, Charron M (2003) The subgrid-scale orographic blocking parametrization of the GEM Model. Atmos Ocean 41(2):155-170

Zadra A, McTaggart-Cowan R, Roch M (2012) Recent changes to the orographic blocking. Seminar presentation, RPN, Dorval, Canada. Retrieved 30 Oct 2013 